\title{
Plasma gasification modeling of municipal solid waste from Jatibarang Landfill in Semarang, Indonesia: analyzing its performance parameters for energy potential
}

\author{
Priyo Adi Sesotyo ${ }^{1, *}$, Muhammad $\mathrm{Nur}^{1,2}$, and Jatmiko Endro Suseno ${ }^{2}$ \\ ${ }^{1}$ Master Program of Energy, School of Postgraduate Studies, Diponegoro University, Semarang - Indonesia \\ ${ }^{2}$ Department of Physics, Faculty of Science and Math, Diponegoro University, Semarang - Indonesia
}

\begin{abstract}
The plasma gasification offers more benefits compared to the conventional gasification. Those benefits include the better environmental issue such as lower emission, variated feedstock and higher energy recovery, including hydrogen and waste heat. Waste to energy technology is developed as a means of waste management to obtain new and renewable energy, due to the increasingly amount of waste produced by the growing population. The feedstock use is municipal solid waste (MSW) from TPA Jatibarang in Semarang City, Central Java. Along with population growth, energy supply becoming a very crucial issue in the near future. Converting the waste to energy would overcome the two crucial issues at once. With high temperature, the plasma gas decompose the feedstock into its constituent element and within thermochemical equilibrium stoichiometry, the syngas was formed. This model was developed based on plasma arc technology and able to estimate the syngas composition, energy required for the reaction and also the $\mathrm{CO} 2$ emission. This study is to obtain the crucial parameter which was involved to get the highest of hydrogen, highest syngas yield, highest efficiencies along with lowest its emission. Results shows that, the use of $100 \%$ steam as gasifying agent and steam to waste ratio (SWR) of $34,48 \%$, can produce $48,33 \%$ of $\mathrm{H} 2$, Syngas Yield is $9,26 \mathrm{Nm} 3 / \mathrm{kg}$, Cold Gasification Efficiency is $58.60 \%$ and its emission is $0.864 \mathrm{~kg} / \mathrm{hr}$.
\end{abstract}

Keywords: Plasma Gasification; Municipal Solid Waste; Syngas Composition; Syngas Yields ; $\mathrm{CO}_{2}$ Emission.

\section{Introduction}

The kind of gas pollution such as greenhouse gases (GHG), especially $\mathrm{CO}_{2}$, due to the exploitation of conventional fossil fuels, exponentially increasing since the invention of Steam Engine during industrial revolution. Global warming is one of the top world concern in the century and must be overcome by reducing the GHG emission. It can be achieved by substitution the consumation of fossil fuel with renewable fuel. Another top world concern is the disposal of solid waste in landfills, due to the contamination of bio-chemical hazardous waste and the emission of GHG.

Sort of regulation and policy related to waste management have already been issued in Indonesia, with the aim is to increase the material recovery (MR) which able to decrease the coverage area needed for disposing the waste on designated land, the better method of energy recovery (ER) due to the energy potential contained, and the minimalisation of the environmental impact (MEI) and public health impact [1].

Waste is one of the abundant resources in the near future and ever since the solid waste is exponentially increasing globally, due to the financial development and increasingly procuring power in most of the countries. Waste can be considered as a appropriate promising new and renewable resource, both 'as a energy and material reserve. Sort of waste, namely as MSW, industrial waste, construction waste, biomass waste, medical waste and hazardous waste. Instead of having some modification for the landfilling those wastes, either using green belts and covering lands, the waste to energy (WTE) technology is the most alternatively method to lessen the amount of waste dispose into the disposal area[2].

Waste incineration, tipically by having the waste is cofired with fossil fuel, either localized or centralized, is a common method in Indonesia, due to the easiest way to reduce the area need for landfill disposal, but unable to do the ER and MEI. Incineration will emmits flue gas which may contained toxic fly ash that violate the

\footnotetext{
* Corresponding author: psesotyo@gmail.com
} 
enviromental standard. Another method for waste management is pyrolysis. Pyrolysis is a combustion process $(400-850 \mathrm{degC})$ with the minimization of oxygen used [1]. It can be applied to the MSW to convert into syngas and residues, such as carbon char and inorganic material (ash) and some high viscous liquid that can be used for fuels.

Gasification is one of the method for waste management, operate at higher temperature (850-1400 $\operatorname{degC}$ ) with oxygen amount is controlled used [1]. By implementing the thermochemical process, gasification converts raw fuel into syngas. The syngas, mainly composed of $\mathrm{CO}$ (carbon monoxyde), $\mathrm{H}_{2}$ (hydrogen), $\mathrm{H}_{2} \mathrm{O}$ (steam/water vapor), $\mathrm{CH}_{4}$ (methane), and other gases such as $\mathrm{HCl}$ (chloric acid), $\mathrm{H}_{2} \mathrm{~S}$ (sulfuric acid), $\mathrm{CO}_{2}$ (carbon dioxide), $\mathrm{O}_{2}$ (oxygen), COS (carbonyl sufide) and also impurities such as tar and ash [1] The feedstock for the gasification can be from coal, biomass, plastics, MSW, wood, tyre, etc. The success story of gasification is a operation of the certain process parameters, including gasification method, type and flow rate of feedstock, type and flow rate of gasifying agent, operating temperature and the residence time [3].

As the newest method of gasification is the introduction of plasma arc as the source of high temperature inside the reactor. It effectively dissolve the either organic and inorganic part of the waste into essential elements and the partly unorganic portion into amalgamated [1]. The gasification is expressed into four phases, namely drying, which release mostly water content in the feedstock; pyrolysis, plasma arc, to supply hot plasma gas into the system and finally the gasification reaction.

While heating up the gas form to generate plasma, gas particles break up with each other, ionizing and creating free electron and ion [4]. Plasma properties has the ability to conduct electrical current [5].

The process of plasma gasification involved very high temperatures in an environment with a little oxygen content. Plasma gasification apply an external heat sources to gasify the gas into plasma and gasify the constituent element into syngas based on thermochemical stoichiometry reaction. Those external heat source can be called a plasma torch, where an energetic electric arc, a high DC current with average DC voltage, is formed between two electrode, which are passed over by a gasifying agent. The temperature of the DC arc is extremely high (roughly $13000 \mathrm{degC}$ ) with gasifying agent is flowing between the electrode [5]. The plasma gas which is an ionized gas, flows away from the electrode, resulting a plasma jet with high energy quantity and high temperature [6]. The temperature where it contact the decomposed feedstock is much lower, between 2700-4500 degC [5].

Waste management by using plasma gasification have multiple benefits. It's because of the high temperature and high energy quantity, the reaction time inside the reactor is fast. it can be concluded that to process a lot of waste, the construction of the reactor can be made into compact size with high temperature resistant metal material. The plasma torch can be considered as a autonomous heat generator, which can be efficiently governmented to adjust the temperature inside the reactor, apart from the fluctuation of the quality and mass flow of the feedstock and the quality and mass flow of the gasifying agent. The detriment of plasma gasification is the massive power needed to ignite up the plasma torch.

This study follows the work of Minutillo et al, where the plasma gasification equilibrium model was named EPJ (EquiPlasmaJet), and the work of Khuriatie et al, where the use of Feedstock MSW from Jatibarang Landfill is implemented and the use of plasma gas with the introduction of using steam as mixture with air. The work of Khuriatie et al also has not explain the relation between Syngas LHV, Reactor Efficiency with the Syngas Yield, $\mathrm{CO}_{2}$ emission and the Carbon Conversion Efficency. The variation of plasma gas flow rate ratio with the feedstock flow rate also has not been explained.

The purpose of this study is to obtain the crucial parameter which was involved to get the highest of $\mathrm{H}_{2}$, highest syngas yield, highest efficiencies along with lowest its emission by using steam as the only plasma gas used. The variation of steam to waste ratio is introduced as the configured simulation which refer to the Gil et al and Diaz et al.

\section{Material and Methodology}

\subsection{Material}

The MSW of Jatibarang Landfill characterized by its HV (Heating Value), Proximate Analysis \& Ultimate Analysis content within.

Table 1. Ultimate analysis MSW [2]

\begin{tabular}{|c|c|}
\hline \multicolumn{2}{|c|}{$\begin{array}{c}\text { Characteristic of MSW Feedstock } \\
\text { Ultimate Analysis (wt. \% db) }\end{array}$} \\
\hline Ash & 9.51 \\
C & 43.71 \\
\hline H & 7.74 \\
\hline N & 1.95 \\
Cl & 0 \\
\hline S & 0.40 \\
\hline O & 36.69 \\
\hline
\end{tabular}

Ultimate analysis is characterize as the total elemental analysis to define the percentage of elements, mainly : Carbon (C), Hydrogen (H), Nitrogen (N), Sulfur (S), Chlorine $(\mathrm{Cl})$ and Oxygen $(\mathrm{O})$.

$\mathrm{O}[\%]=100[\%]-\mathrm{C}[\%]-\mathrm{H}[\%]-\mathrm{N}[\%]-\mathrm{S}[\%]-\mathrm{Cl}[\%]$

Table 2. Proximate analysis MSW[2]

\begin{tabular}{|l|r|}
\hline \multicolumn{2}{|c|}{ Proximate Analysis (wt. \%) } \\
\hline Water Content & 20 \\
\hline Fixed Carbon & 12.82 \\
\hline Volatile Matter & 77.67 \\
\hline Ash & 9.51 \\
\hline
\end{tabular}


Proximate analysis is characterize of moisture (M) and ash content (the uncombustible content of MSW), volatile matter (VM) and fixed carbon (FC).

$$
\mathrm{FC}[\%]=100[\%]-\mathrm{M}[\%]-\mathrm{Ash}[\%]-\mathrm{VM}[\%]
$$

Table 3. Heating value MSW[2]

\begin{tabular}{|l|l|}
\hline \multicolumn{2}{|c|}{ Heating Value $(\mathrm{kJ} / \mathrm{kg})$} \\
\hline HHV & 18.53 \\
\hline LHV & 16.01 \\
\hline
\end{tabular}

The heat value of waste is straight corresponding to the carbon content of the waste and contrary corresponding to the ash and moisture content. Low heat value (LHV) is the nett heat accessible for volatile material of the MSW while the high heat value (HHV) includes the inherent heat of vaporization also. These are predicted based on the chemical balance of the waste material.

\subsection{Methodology}

The simulation method for this study, will rely on the sequence workflow of preparing the model, with the feedstock proximate and ultimate propertis key in as the input. Process parameter (main asumption), decomposing formula and chemical reaction will be key in later in order to have the $\%$ mol results $\left(\mathrm{H}_{2}, \mathrm{CO}, \mathrm{CH}_{4}\right)$ with little variation within the reference model with the same feedstock properties and process properties. The observed process parameter to be key in later based on the prepared schenario to have the $\%$ mol results and the other results parameter as the required input for the calculation of performance parameter (Syngas Yield, Syngas LHV, Carbon Conversion Efficiency (Xc) and Cold Gas Efficiency (CGE)). Analyst to be conduct to the performance parameter to observe the best process parameter will result in better $\mathrm{H}_{2}$ generation.

\subsection{Modeling}

Within this study, the plasma gasification behaviour has been explored, considered and analyzed by scientific model accordingly developed by the applying the thermochemical symmetry approach as stated in the reference.

On the Fig. 1, there is a flowsheet of plasma gasificaation model, termed as EquiPlasmaJet (EPJ), developed by Minutillo, et all 2009 with little modification to consider the stoichiometric chemical equilibrium, to determine the \% mol of the each Syngas composition as the product and Table 4, show a brief decription of the main blocks incorporated being used to model the process. Considering only the organic portion of the solid waste is gasified, the EPJ model will neglect the inorganic portion, as specified above, will be amalgamate.

With normal temperature figure inside the Gasification reactor, the process is splitted into two reaction zone for the convention of the modelling. It results by having two reactor, HTR (high temperature reactor), in which the thermochemical symmetry is achieved by a non-stoichiometric formulation and LTR (low temperatur reactor), in which the thermochemical symmetry is achieved by a stoichiometric framework. In the HTR, equilibrium composition is achieved by direct minization of the Gibbs free energy for a accord set of expected product beyond the specific chemical reaction. The HTR reactor, expected to operate at the average temperature of $2500 \mathrm{degC}$, simulates the targeted reaction zone of the plasma gasification system, where the plasma torch directly impact the treated MSW. In the LTR reactor, expected to operate at the average temperature of $1250 \operatorname{degC}$, the gasification process is completed with known chemical reaction occurs and the organic decomposed element is converted into a syngas.

Table 4. Main block description

\begin{tabular}{|l|l|l|}
\hline $\begin{array}{l}\text { Block } \\
\text { Name }\end{array}$ & $\begin{array}{l}\text { Block } \\
\text { Type }\end{array}$ & Description \\
\hline DRYER & RYield & $\begin{array}{l}\text { Non-Stoichiometric } \\
\text { reactor based on } \\
\text { expected Yield element } \\
\text { Dissemination from } \\
\text { Calculator Feature }\end{array}$ \\
\hline HTR & RGibbs & $\begin{array}{l}\text { Rigorous Hydrate } \\
\text { Reactor and multiphase } \\
\text { symmetry based on } \\
\text { Gibbs Free Energy } \\
\text { Minimalization }\end{array}$ \\
\hline LTR & RStoic & $\begin{array}{l}\text { Stoichiometric reactor } \\
\text { with expected element }\end{array}$ \\
\hline $\begin{array}{l}\text { HEX1 \& } \\
\text { HEX2 }\end{array}$ & Heater & $\begin{array}{l}\text { Simple Thermal heat } \\
\text { exchanger }\end{array}$ \\
\hline SEP & Separator & $\begin{array}{l}\text { Water separation from } \\
\text { Feedstock }\end{array}$ \\
\hline DC-ARC & Heater & $\begin{array}{l}\text { Simple Electric Thermal } \\
\text { Conversion }\end{array}$ \\
\hline MIX & Mixer & Material Stream Mixer \\
\hline
\end{tabular}

A DRYER is located before the HTR reactor as a means of decompose the waste into organic fraction. Within this block, waste yield dissemination is specified by the help of fortran calculator bestow to the proximate and ultimate analysis, the organic fraction of the waste is dissolve into its molecular element. The surplus heat correlate with the disintegrated waste is considered in the plasma gasification energy equity as a 'heat stream' (HEAT1) that connect the DRYER with the HTR reactor.

Plasma jet apparatus, modeled by a DC-ARC which supplied the heat required to make the plasma gas. The PLASMA stream and the power utilization of the plasma torch is calculated by the thermal power conveyed into the stream STEAM in the DC-ARC heat exchanger with described ratio between the energy conveyed to the steam and the energy utilization.

Since the waste is gravitationally flow descending of the gasification reactor, it is preheated by the hot syngas that flow ascending. The moisture content from the 
waste dissapear due to the hot syngas and leaves the reactor together with the syngas. The block model heat exchanger HEX1 for solid waste (ORG1) and the HEX2 for gas phase (HOTGAS), the waste separation unit SEP and the stream mixer (MIX) have been selected in the plasma gasification reactor model.

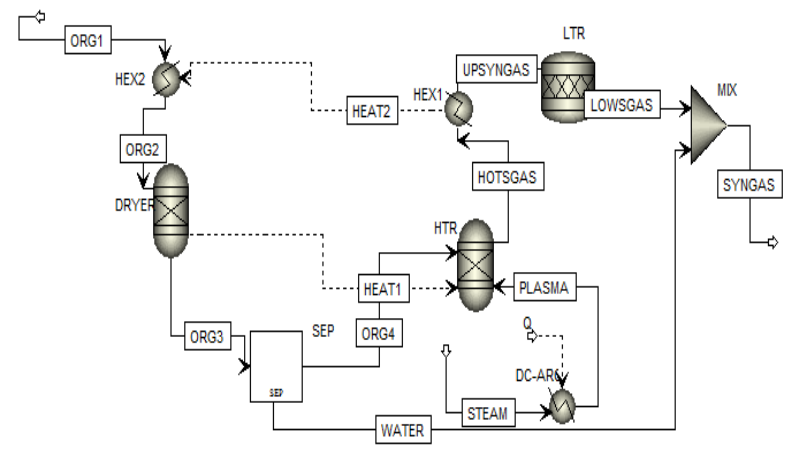

Fig. 1. Gasification Process model (modified EPJ model).

\subsection{Model Validation}

It is required to validate the modified EPJ model, by having result from the RDF (refuse derived fuel) used by Minutillo, Perna and Bona, 2009, is testing using air as the plasma gas. The model has the atmospheric pressure and the plasma gas to feedstock ratio of 0.782 . The composition of RDF is given in Tabel 5.

Table 5. RDF composition and heating value [1]

\begin{tabular}{|c|c|}
\hline Proximate $(\% \mathrm{~mol})$ & \\
\hline Moisture & 20 \\
\hline $\mathrm{FC}$ & 10.23 \\
\hline VM & 75.96 \\
\hline Ash & 13.81 \\
\hline \multicolumn{2}{|l|}{ Ultimate $(\% \mathrm{~mol})$} \\
\hline Ash & 13.81 \\
\hline $\mathrm{C}$ & 48.23 \\
\hline $\mathrm{H}$ & 6.37 \\
\hline $\mathrm{N}$ & 1.22 \\
\hline $\mathrm{CI}$ & 1.13 \\
\hline $\mathrm{S}$ & 0.76 \\
\hline $\mathrm{O}$ & 28.48 \\
\hline MSW HHV $(\mathrm{Mj} / \mathrm{kg})$ & 17.8 \\
\hline
\end{tabular}

A comparison between the Syngas Composition by modifed model (see Fig. 2) (using air as plasma gas) and those obtained by Minutillo, Perna and Bona, 2009 are summarized in Tabel 6 , showing toleratable results.

Table 6. Result comparison

\begin{tabular}{|r|r|r|}
\hline $\begin{array}{r}\text { Syngas } \\
\text { Composition (\% } \\
\text { mol) }\end{array}$ & $\begin{array}{r}\text { Minutillo, } \\
\text { Perna and } \\
\text { Bona, 2009 }\end{array}$ & $\begin{array}{r}\text { Simulation } \\
\text { from modified } \\
\text { model }\end{array}$ \\
\hline $\mathrm{N} 2$ & 26.97 & 27.43 \\
\hline $\mathrm{H} 2 \mathrm{O}$ & 11.68 & 13.99 \\
\hline $\mathrm{CO}$ & 33.79 & 32.28 \\
\hline $\mathrm{CO} 2$ & 0.00 & 0.00 \\
\hline $\mathrm{H} 2$ & 21.04 & 20.01 \\
\hline $\mathrm{H} 2 \mathrm{~S}$ & 0.22 & 0.22 \\
\hline $\mathrm{CH} 4$ & 5.97 & 5.73 \\
\hline
\end{tabular}

\begin{tabular}{|r|r|r|}
\hline $\begin{array}{r}\text { COS (Carbonyl } \\
\text { Sulfide) }\end{array}$ & 0.02 & 0.02 \\
\hline HCI & 0.32 & 0.32 \\
\hline CI2 & 0.00 & 0.00 \\
\hline C & 0.00 & 0.00 \\
\hline S & 0.00 & 0.00 \\
\hline O2 & 0.00 & 0.00 \\
\hline
\end{tabular}

The difference between the reference [1] and the simulation result, especially \% mol of $\mathrm{CO}, \mathrm{H}_{2}$ and $\mathrm{CH}_{4}$, is less than $10 \%$, so it can be considered similar.

\subsection{Gasification Reaction}

The chemical reactions which occur in the LTR gasification reactor can be summarized as follows :

$\mathrm{C}+\mathrm{H}_{2} \mathrm{O} \rightarrow \mathrm{CO}+\mathrm{H}_{2}$ (water gas shift reaction)

$\mathrm{C}+\mathrm{CO}_{2} \rightarrow 2 \mathrm{CO}$ (boudard symmetry reaction)

$\mathrm{C}+\mathrm{O}_{2} \rightarrow \mathrm{CO}_{2}$ (oxidation of carbon reaction)

$\mathrm{C}+2 \mathrm{H}_{2} \rightarrow \mathrm{CH}_{4}$ (methane production reaction)

$\mathrm{S}+\mathrm{H}_{2} \rightarrow \mathrm{H}_{2} \mathrm{~S}$ (hydrogen sulfide synthesis reaction)

$\mathrm{H}_{2}+\mathrm{Cl}_{2} \rightarrow 2 \mathrm{HCl}$ (hydrogen chloride synthesis reaction)

$\mathrm{H}_{2} \mathrm{~S}+\mathrm{CO}_{2} \rightarrow \mathrm{COS}+\mathrm{H}_{2} \mathrm{O}$ (hydrolisis carbonyl sulfide)

Those chemical reactions are fits in with the composition of the feedstock (see Table 5) and the product results within the simulation software (see Table 6)

\subsection{Boundary condition and assumptions}

The Plasma Gasification Reactor model is assumed to be:

- Steady state

- The process is considered isobaric and adiabatic

- The HCoalgen and DCoalligt property models were used to predict biomass forming enthalpy, specific heat capacity in constant pressure and chemical density based on the proximate and ultimate analysis.

- The chemical element \& compound involved in the model are : $\mathrm{H}_{2}, \mathrm{O}_{2}, \mathrm{~N}_{2}, \mathrm{CO}, \mathrm{CO}_{2}, \mathrm{CH}_{4}, \mathrm{H}_{2} \mathrm{O}, \mathrm{C}, \mathrm{Cl}$, $\mathrm{S}, \mathrm{H}_{2} \mathrm{~S}, \mathrm{~S}, \mathrm{COS}$.

- Ash is considered a non-reactive non-conventional solid.

- Modeling approch use is thermochemical equilibrium stoichiometric

Table 7. Main assumption for the simulation

$\left.\begin{array}{|r|r|}\hline \multicolumn{2}{|c|}{\text { Main assumption for simulation }} \\ \hline \text { Gasifying Agent type } & 100 \% \text { Steam } \\ \hline \text { Gasification Pressure (atm) } & 1 \\ \hline \text { Plasma Temperature (degC) } & 4000 \\ \hline \text { Syngas Temperature (degC) } & 1250 \\ \hline \text { Feedstock mass flow (kg/hr) } & 29 \\ \hline \text { Plasma Torch Efficiency } \\ (\%)\end{array}\right)$




\begin{tabular}{|r|r|}
\hline $\begin{array}{r}\text { Ambient Temperature } \\
(\operatorname{degC})\end{array}$ & 25 \\
\hline $\begin{array}{r}\text { Gasifying Agent } \\
\text { Temperature }(\operatorname{degC})\end{array}$ & 120 \\
\hline
\end{tabular}

The modified model, after its result has been validated, is tested in a study of three of gasification parameter, which is gasifying agent mass flow and steam to waste ratio (SWR). The \% Mol of $\mathrm{H}_{2}$, LHV of Syngas, Yield Syngas, Carbon Conversion Efficiency, Mechanical Gasification Efficiency, Cold Gas Efficiency and $\mathrm{CO}_{2}$ Emission for each process parameter are also analyzed.

\section{Results and discussion}

\subsection{Simulation result}

The modified EPJ model will be employeed to estimate the syngas balance, syngas yield, and the $\mathrm{CO}_{2}$ emission. To define the optimal performance parameter of the Plasma Gasification Process, five difference configuration have been investigate based on the value described by :

- Steam mass flow : $10-12 \mathrm{~kg} / \mathrm{hr}$ [3]

- Steam to waste ratio : $0.53-1.1$ [7]

Table 8. Five configuration for the simulation

\begin{tabular}{|c|c|c|c|}
\hline $\begin{array}{l}\text { Config } \\
\text { uration }\end{array}$ & SWR & $\begin{array}{l}\text { Feedstock } \\
\text { Massflow }(\mathrm{kg} / \mathrm{s})\end{array}$ & $\begin{array}{l}\text { Steam } \\
\text { MassFlow } \\
(\mathrm{kg} / \mathrm{s})\end{array}$ \\
\hline 1 & 0.345 & 0.008055556 & 0.00277778 \\
\hline 2 & 0.414 & 0.008055556 & 0.00333333 \\
\hline 3 & 0.530 & 0.008055556 & 0.00426944 \\
\hline 4 & 0.815 & 0.008055556 & 0.00656528 \\
\hline 5 & 1.100 & 0.008055556 & 0.00886111 \\
\hline
\end{tabular}

The configuration 3 and 5, are refering to the SWR, published by Gil et al and configuration 1 and 2, are refering to the Steam mass flow, published by Diaz et al. And the configuration 4 , are known by interpolating the configuration 3 and 5 .

Table 9. Five configuration simulation with its results

\begin{tabular}{|l|c|c|c|c|c|}
\hline Result & $\begin{array}{l}\text { Confi } \\
\text { gurati } \\
\text { on 1 }\end{array}$ & $\begin{array}{l}\text { Confi } \\
\text { gurati } \\
\text { on 2 }\end{array}$ & $\begin{array}{l}\text { Confi } \\
\text { gurati } \\
\text { on 3 }\end{array}$ & $\begin{array}{c}\text { Confi } \\
\text { gurati } \\
\text { on 4 }\end{array}$ & $\begin{array}{l}\text { Con } \\
\text { figu } \\
\text { rati } \\
\text { on 5 }\end{array}$ \\
\hline $\begin{array}{l}\text { PGZ- } \\
\text { HTR } \\
\text { Temperat } \\
\text { ur (degC) }\end{array}$ & $\begin{array}{c}4071 . \\
36\end{array}$ & $\begin{array}{c}3841 . \\
03\end{array}$ & $\begin{array}{c}3546 . \\
84\end{array}$ & $\begin{array}{c}3060 . \\
3\end{array}$ & $\begin{array}{c}270 \\
4.38\end{array}$ \\
\hline $\begin{array}{l}\text { Syngas } \\
\begin{array}{l}\text { Temperat } \\
\text { ure } \\
\text { (degC) }\end{array}\end{array}$ & $\begin{array}{c}1242 . \\
21\end{array}$ & $\begin{array}{c}1242 . \\
62\end{array}$ & $\begin{array}{c}1243 . \\
21\end{array}$ & $\begin{array}{c}1244 . \\
32\end{array}$ & $\begin{array}{c}124 \\
5.12 \\
1\end{array}$ \\
\hline
\end{tabular}

\begin{tabular}{|c|c|c|c|c|c|}
\hline $\begin{array}{l}\text { Syngas } \\
\text { mass } \\
\text { flow } \\
(\mathrm{kg} / \mathrm{s})\end{array}$ & 0.01 & 0.01 & 0.01 & 0.01 & 0.02 \\
\hline $\begin{array}{l}\text { Syngas } \\
\text { volumetr } \\
\text { ic flow } \\
(\mathrm{m} 3 / \mathrm{s})\end{array}$ & 0.09 & 0.10 & 0.10 & 0.12 & 0.13 \\
\hline $\begin{array}{l}\text { Syngas } \\
\text { Density } \\
(\mathrm{kg} / \mathrm{m} 3)\end{array}$ & 0.12 & 0.12 & 0.12 & 0.12 & 0.13 \\
\hline $\begin{array}{l}\text { Syngas } \\
\text { Composi } \\
\text { tion } \\
(\% \mathrm{~mol})\end{array}$ & & & & & \\
\hline N2 & 0.61 & 0.58 & 0.55 & 0.47 & 0.42 \\
\hline $\mathrm{H} 2 \mathrm{O}$ & 18.06 & 20.58 & 25.12 & 35.30 & $\begin{array}{c}42.9 \\
0\end{array}$ \\
\hline $\mathrm{CO}$ & 30.94 & 29.31 & 26.93 & 22.32 & $\begin{array}{c}18.8 \\
4 \\
\end{array}$ \\
\hline $\mathrm{CO} 2$ & 0.74 & 1.04 & 1.51 & 2.44 & 3.06 \\
\hline $\mathrm{H} 2$ & 48.34 & 47.03 & 44.55 & 38.84 & $\begin{array}{c}34.5 \\
6 \\
\end{array}$ \\
\hline $\mathrm{H} 2 \mathrm{~S}$ & 0.05 & 0.05 & 0.05 & 0.04 & 0.04 \\
\hline $\mathrm{CH} 4$ & $\begin{array}{c}2.30 \mathrm{E} \\
-09\end{array}$ & $\begin{array}{c}1.90 \mathrm{E} \\
-09\end{array}$ & $\begin{array}{c}1.55 \mathrm{E} \\
-09\end{array}$ & $\begin{array}{c}1.31 \mathrm{E} \\
-09\end{array}$ & $\begin{array}{c}1.51 \\
\mathrm{E}- \\
09 \\
\end{array}$ \\
\hline $\begin{array}{l}\text { COS } \\
\text { (carbonyl } \\
\text { sulfide) }\end{array}$ & $\begin{array}{c}5.93 \mathrm{E} \\
-02\end{array}$ & $\begin{array}{c}5.61 \mathrm{E} \\
-02\end{array}$ & $\begin{array}{c}5.18 \mathrm{E} \\
-02\end{array}$ & $\begin{array}{c}4.44 \mathrm{E} \\
-02\end{array}$ & $\begin{array}{c}3.89 \\
\text { E- } \\
02 \\
\end{array}$ \\
\hline $\mathrm{HCl}$ & 0 & 0 & 0 & 0 & 0 \\
\hline $\mathrm{Cl} 2$ & 0 & 0 & 0 & 0 & 0 \\
\hline $\mathrm{C}$ & 0 & 0 & 0 & 0 & 0 \\
\hline S & 0 & 0 & 0 & 0 & 0 \\
\hline $\mathrm{O} 2$ & 1.22 & 1.36 & 1.24 & 0.55 & 0.14 \\
\hline $\begin{array}{l}\mathrm{CO} 2 \\
\text { emission } \\
(\mathrm{kg} / \mathrm{s})\end{array}$ & $\begin{array}{c}2.40 \mathrm{E} \\
-04\end{array}$ & $\begin{array}{c}3.52 \mathrm{E} \\
-04\end{array}$ & $\begin{array}{c}5.46 \mathrm{E} \\
-04\end{array}$ & $\begin{array}{c}1.01 \mathrm{E} \\
-03\end{array}$ & $\begin{array}{c}1.44 \\
\mathrm{E}- \\
03\end{array}$ \\
\hline
\end{tabular}

The performance parameter have been evaluated, based on the result shown in Table 9, which can be seen below :

Table 10. Five configured simulation with its performance parameter

\begin{tabular}{|c|c|c|c|c|c|c|}
\hline \multicolumn{2}{|c|}{$\begin{array}{l}\text { Gassification } \\
\text { Agent }\end{array}$} & $\begin{array}{l}100 \\
\% \\
\text { Stea }\end{array}$ & $\begin{array}{l}100 \% \\
\text { Steam( } \\
\text { 2) }\end{array}$ & $\begin{array}{l}100 \\
\% \\
\text { Stea }\end{array}$ & $\begin{array}{l}100 \\
\% \\
\text { Stea }\end{array}$ & $\begin{array}{l}100 \% \\
\text { Steam }(5\end{array}$ \\
\hline $\begin{array}{l}\text { Plasma } \\
\text { Gas }\end{array}$ & $\begin{array}{l}\text { Steam } \\
\text { Mass } \\
\text { Flow } \\
(\mathrm{kg} / \mathrm{s}) \\
\end{array}$ & $\begin{array}{l}0.00 \\
278\end{array}$ & $\begin{array}{l}0.003 \\
33\end{array}$ & $\begin{array}{l}0.00 \\
427\end{array}$ & $\begin{array}{l}0.00 \\
657\end{array}$ & $\begin{array}{l}0.0088 \\
61\end{array}$ \\
\hline Output & $\begin{array}{l}\text { Syngas } \\
\text { Temp(d } \\
\text { egC) }\end{array}$ & $\begin{array}{l}1242 \\
.21\end{array}$ & $\begin{array}{l}1242 . \\
62\end{array}$ & $\begin{array}{l}1243 \\
.21\end{array}$ & $\begin{array}{l}1244 \\
.32\end{array}$ & $\begin{array}{l}1244.3 \\
22\end{array}$ \\
\hline
\end{tabular}




\begin{tabular}{|c|c|c|c|c|c|c|}
\hline $\begin{array}{l}\text { Emissi } \\
\text { on }\end{array}$ & $\begin{array}{l}\text { Emissi } \\
\text { on CO2 } \\
(\mathrm{kg} / \mathrm{s})\end{array}$ & $\begin{array}{l}0.00 \\
024\end{array}$ & $\begin{array}{l}0.000 \\
35\end{array}$ & $\begin{array}{l}0.00 \\
055\end{array}$ & $\begin{array}{l}0.00 \\
101\end{array}$ & $\begin{array}{l}0.0014 \\
39\end{array}$ \\
\hline \multirow{2}{*}{$\begin{array}{l}\text { Gas } \\
\text { Compo } \\
\text { sition } \\
\text { (dry } \\
\text { basis) } \\
\end{array}$} & $\begin{array}{l}\mathrm{H} 2 \\
(\% \mathrm{~mol})\end{array}$ & $\begin{array}{l}48.3 \\
367 \\
\end{array}$ & $\begin{array}{l}47.02 \\
55 \\
\end{array}$ & $\begin{array}{l}44.5 \\
501 \\
\end{array}$ & $\begin{array}{l}38.8 \\
364 \\
\end{array}$ & $\begin{array}{l}34.562 \\
61 \\
\end{array}$ \\
\hline & $\begin{array}{l}\mathrm{CO} \\
(\% \mathrm{~mol})\end{array}$ & $\begin{array}{l}30.9 \\
359\end{array}$ & $\begin{array}{l}29.31 \\
09\end{array}$ & $\begin{array}{l}26.9 \\
326\end{array}$ & $\begin{array}{l}22.3 \\
228\end{array}$ & $\begin{array}{l}18.835 \\
42\end{array}$ \\
\hline \multirow[t]{2}{*}{ Yields } & $\begin{array}{l}\text { Yield } \\
\text { Syngas } \\
(\mathrm{Nm} 3 / \mathrm{k} \\
\mathrm{g})\end{array}$ & $\begin{array}{l}9.25 \\
923\end{array}$ & $\begin{array}{l}9.195 \\
3\end{array}$ & $\begin{array}{l}9.07 \\
02\end{array}$ & $\begin{array}{l}8.78 \\
915\end{array}$ & $\begin{array}{l}8.5955 \\
43\end{array}$ \\
\hline & $\begin{array}{l}\text { LHV } \\
\text { Syngas } \\
\text { (MJ/N } \\
\text { m3) }\end{array}$ & $\begin{array}{l}9.88 \\
719\end{array}$ & $\begin{array}{l}9.543 \\
64\end{array}$ & $\begin{array}{l}8.96 \\
637\end{array}$ & $\begin{array}{l}7.71 \\
87\end{array}$ & $\begin{array}{l}6.7735 \\
54\end{array}$ \\
\hline \multirow[t]{3}{*}{$\begin{array}{l}\text { Efficie } \\
\text { ncy }\end{array}$} & $\begin{array}{l}\text { Carbon } \\
\text { Conver } \\
\text { sion } \\
\text { Eff(\%) }\end{array}$ & $\begin{array}{l}3.60 \\
114\end{array}$ & $\begin{array}{l}3.426 \\
4\end{array}$ & $\begin{array}{l}3.16 \\
738\end{array}$ & $\begin{array}{l}2.67 \\
198\end{array}$ & $\begin{array}{l}2.3105 \\
77\end{array}$ \\
\hline & $\begin{array}{l}\text { Mecha } \\
\text { nical } \\
\text { Gasific } \\
\text { ation } \\
\text { Eff(\%) }\end{array}$ & $\begin{array}{l}70.0 \\
312\end{array}$ & $\begin{array}{l}70.57 \\
34\end{array}$ & $\begin{array}{l}70.7 \\
789\end{array}$ & $\begin{array}{l}70.0 \\
399\end{array}$ & $\begin{array}{l}69.548 \\
25\end{array}$ \\
\hline & $\begin{array}{l}\text { Cold } \\
\text { Gasific } \\
\text { ation } \\
\text { Eff(\%) }\end{array}$ & $\begin{array}{l}58.6 \\
014\end{array}$ & $\begin{array}{l}57.18 \\
84\end{array}$ & $\begin{array}{l}54.4 \\
545\end{array}$ & $\begin{array}{l}47.9 \\
403\end{array}$ & $\begin{array}{l}42.873 \\
19\end{array}$ \\
\hline
\end{tabular}

The performance parameter formula as follows : $L H V_{\text {Syngas }}=\mathrm{HHV}-10.79 Y_{\mathrm{H}_{2}}+12.62 Y_{\mathrm{CO}}+35.81 Y_{\mathrm{CH}_{4}}$

Where $\mathrm{Y}$ is the \% volume of mentioned syngas components and LHV in $(\mathrm{MJ} / \mathrm{Nm} 3)$

$$
\text { Yield }=\frac{V}{m}
$$

Syngas Yield, with $\mathrm{V}$ as the volumetric flow rate of the syngas $(\mathrm{Nm} 3 / \mathrm{s})$ and $\mathrm{m}$ as the feedstock mass flow rate of the syngas $(\mathrm{kg} / \mathrm{s})$

$$
\mathrm{CGE}=\frac{L_{\text {SHy }} \text { sas } F_{\text {syngas }}}{L H V_{R D F} \dot{m}_{R D F}+P_{\text {plasma }}} * 100 \%
$$

CGE as the Cold Gasification Efficiency, LHV Syngas $_{\text {in }}$ $(\mathrm{MJ} / \mathrm{Nm} 3), \mathrm{F}_{\text {syngas }}$ as teh volumetric flow rate of syngas $(\mathrm{Nm} 3 / \mathrm{s}), \mathrm{LHV}_{\mathrm{MSW}}$ in $(\mathrm{MJ} / \mathrm{kg}), \dot{\mathrm{m}}_{\mathrm{MSW}}$ as the feedstock mass flow rate $(\mathrm{kg} / \mathrm{s})$ and $\mathrm{P}_{\text {plasma }}$ as te power consume to supply the plasma torch.

The following figure show the trends as per the configuration 1 to configuration 5

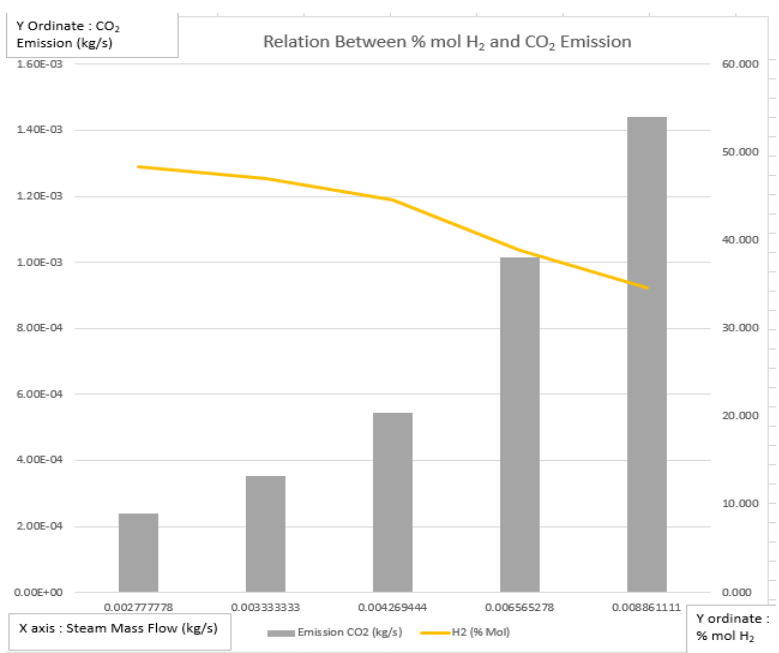

Fig. 2. Trends on $\% \mathrm{~mol} \mathrm{H} 2$ and $\mathrm{CO}_{2}$ emission

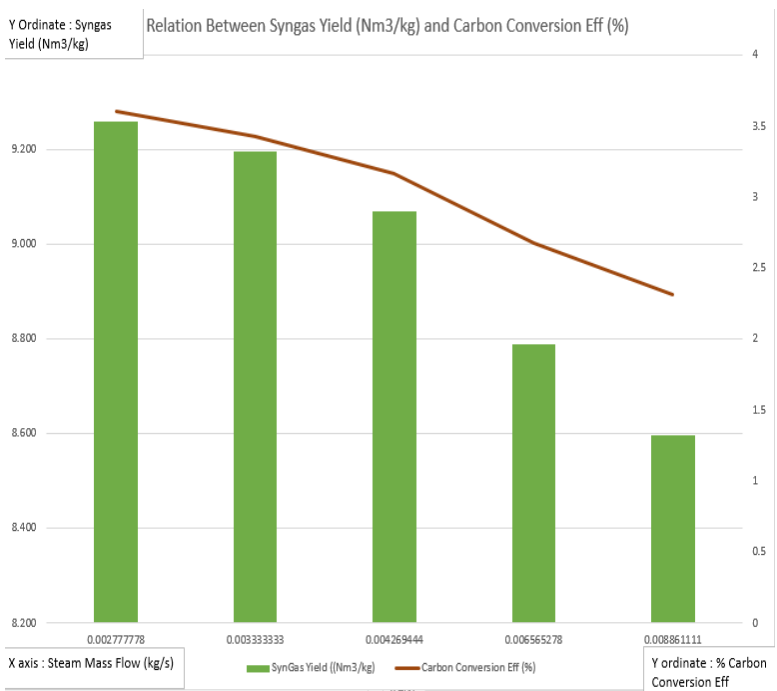

Fig. 3. Trends on Syngas Yield and Carbon Conversion Eff.

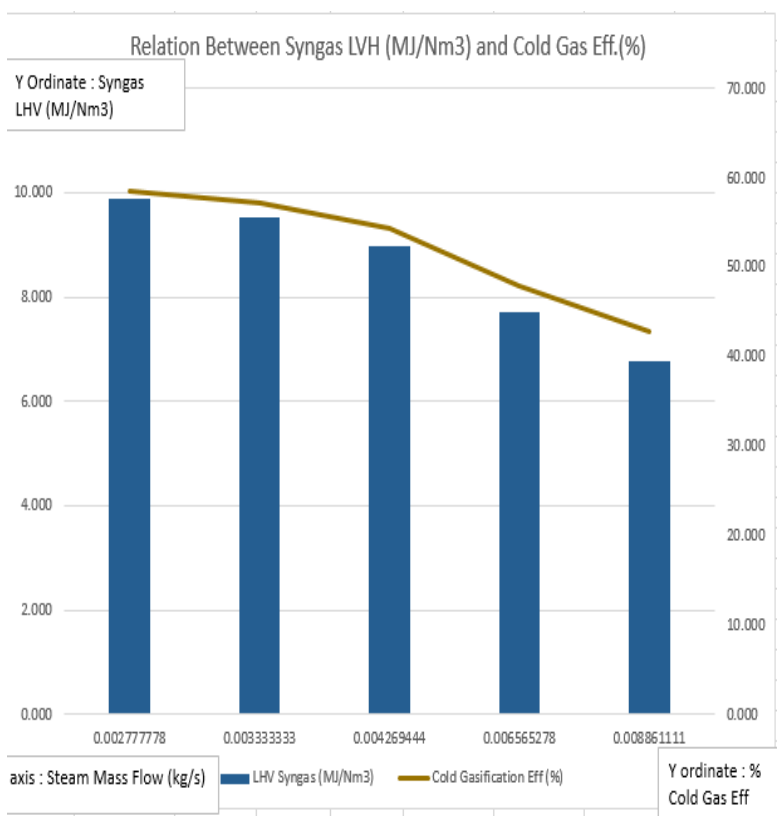

Fig. 4. Trends on Syngas LHV and \% Cold Gasification Eff. 


\subsection{Simulation result analysis}

The decline value of $\mathrm{CO}$ and $\mathrm{H}_{2} \% \mathrm{~mol}$ are altered by the temperature values, since a greater temperature values is required by the endothermic reaction, causing lower rate of the Water Gas Shift reaction and automatically reduce these elements, since water gas shift is an endothermic reaction. As per table 9, the lower \% mol of these gases, the higher syngas temperature.

The reason to use $100 \%$ steam to be the gasifying agent is to enrich the $\% \mathrm{~mol}$ of $\mathrm{H}_{2}$ in the syngas [5] and has the favor by proposing more hydrogen atom into the reactor, thereby develop the condition of the syngas, but detriment the escalation of the cost of power utilized. As expected, the use of steam, resulting in greater partial pressure of water vapor inside the system, which needed by the water gas shift reaction, resulted to the escalation of $\mathrm{H}_{2}$ production.

Combining the two of process parameter mentioned previously, SWR and the Steam mass flow, resulting the change of the \% mol of $\mathrm{H}_{2}$ in Syngas, also the other process parameter such as syngas volumetric flow, syngas density, the syngas temperature and $\mathrm{CO}_{2}$ emission. Among the five configurations as per Table 8, the $1^{\text {st }}$ configuration give the highest $\mathrm{H}_{2} \%$ mol, which is $48,34 \%$, also give the lowest $\mathrm{CO}_{2}$ emission, which is $2.4 * 10^{-4} \mathrm{~kg} / \mathrm{s}$. (see Table 9). The $1^{\text {st }}$ configuration, shows the smallest steam flow rate and the smallest SWR and the $5^{\text {th }}$ configuration, shows the highest steam flow and the highest SWR. The injection of steam as gasifying agent has to be in proportional with the waste mass flow rate.

The lower the SWR, the better result of $\% \mathrm{~mol} \mathrm{H}_{2}$ thus there is an option to save energy from generating steam, save the water as a raw material to generate steam and reduce the $\mathrm{CO}_{2}$ emission (see Fig. 2). The more steam introduce to the reactor, the carbon conversion efficiency becoming worse and syngas yield also decreasing (see Fig. 3). Therefore resulting in the greater concentration of water is found in the syngas and automatically decline the gasification efficiency. The less contamination of carbon and the more oxygen contamination in the ultimate analysis of feedstock, implied a low LHV of the feedstock, resulting in the more plasma power consume to reach the required gasifier temperature. The syngas LHV and Cold Gas efficiency should decrease with the increasing SWR (see Fig. 4).

\section{Conclusion}

The highest reactor efficiency, the highest quality of syngas and the lowest $\mathrm{CO}_{2}$ emission when the $\mathrm{SWR}$ is on 0.345 and the steam mass flow rate is on $10 \mathrm{~kg} / \mathrm{hr}$. The higher SWR, the lower efficiency, lower syngas quality and higher $\mathrm{CO}_{2}$ emission.

\section{References}

1. M. Minutillo, A. Perna, and D. Di Bona, Modelling and performance analysis of an integrated plasma gasification combined cycle (IPGCC) power plant, Energy Convers. Manag., 50, pp. 2837-2842, (2009).

2. A. Khuriati, P. Purwanto, H. Setiyo Huboyo, S. Suryono, and A. Bawono Putro, Application of aspen plus for municipal solid waste plasma gasification simulation: case study of Jatibarang Landfill in Semarang Indonesia, J. Phys. Conf. Ser., 1025, 1, pp. 1-7, (2018).

3. G. Diaz, N. Sharma, E. Leal-Quiros, and A. Munoz-Hernandez, Enhanced hydrogen production using steam plasma processing of biomass: Experimental apparatus and procedure, Int. J. Hydrogen Energy, 40, 5, pp. 2091-2098, (2015).

4. N. B. and A. D. M. Nur, Ionic Wind Phenomenon and Charge Carrier Mobility in Very High Density Argon Corona Discharge Plasma, J. Phys. Conf. Ser., 012041, (2014).

5. J. Favas, E. Monteiro, and A. Rouboa, Hydrogen production using plasma gasification with steam injection, Int. J. Hydrogen Energy, 42, no. 16, pp. 10997-11005, (2017).

6. I. Janajreh, S. S. Raza, and A. S. Valmundsson, Plasma gasification process: Modeling, simulation and comparison with conventional air gasification, Energy Convers. Manag., 65, pp. 801-809, (2013).

7. J. Gil, J. Corella, M. P. Aznar, and M. A. Caballero, Biomass gasification in atmospheric and bubbling fluidized bed: Effect of the type of gasifying agent on the product distribution, Biomass and Bioenergy, 17, no. 5, pp. 389-403, (1999). 